\title{
FAKTOR-FAKTOR PSIKOLOGIS YANG MEMENGARUHI PERENCANAAN KARIR SISWA
}

Oleh:

\author{
Winda Wulandari ${ }^{1)}$ Nani Restati Siregar ${ }^{2)}$ \\ 1) 2) Jurusan Bimbingan dan Konseling \\ Fakultas Keguruan dan Ilmu Pendidikan, Universitas Halu Oleo \\ Email: ${ }^{1)}$ windabk2014@gmail.com ${ }^{2)}$ naniresilham@yahoo.com
}

\begin{abstract}
ABSTRAK
Penelitian ini bertujuan untuk mengetahui faktor-faktor psikologis yang memengaruhi perencanaan karir pada siswa SMP Negeri 1 Konawe. Penelitian ini merupakan penelitian kuantitatif dengan menggunakan teknik deskriptif. Populasi dalam penelitian ini berjumlah 354 dan sampel dalam penelitian ini berjumlah 35 siswa. Data dikumpulkan dengan menggunakan skala faktor-faktor psikologis yang memengaruhi perencanaan karir siswa. Data di dalam penelitian ini diolah dengan menggunakan statistika deskriptif, berdasarkan hasil analis data ditemukan bahwa faktor self-efficacy berpengaruh besar terhadap perencanaan karir siswa. Adapun faktor skill, pengetahuan dan konsep diri berpengaruh sedang. Berdasarkan hasil tersebut disimpulkan bahwa selfefficacy merupakan faktor dominan yang memengaruhi perencanaan karir siswa SMP Negeri 1 Konawe.
\end{abstract}

Kata Kunci: Faktor Psikologis, Perencanaan Karir

PSYCHOLOGICAL FACTORS AFFECTING CAREER PLANNING OF STUDENTS

\begin{abstract}
This research use quantitative approach with quantitative descriptive. The population in this study amounted to 354 Samples of this research were 35 students. Data were collected by psychological factors affecting career planning of students scales. . The data in this study were processed using descriptive statistics, Based on results of data analysis found that the factors of self-efficacy have a big influence on student career planning. The factors of skill, knowledge, and self-concept are influential. Based on these results it was concluded that self-efficacy was the dominant factor influencing the career planning of students of SMP Negeri 1 Konawe.
\end{abstract}

Keywords: Psychological Factors, Career Planning 


\section{Pendahuluan}

Pendidikan memunyai peran yang sangat menentukan baik bagi kepentingan negara ataupun masyarakat dan khususnya bagi siswa itu sendiri. Menurut Yusuf \& Nurihsan (2006: 3) pendidikan merupakan faktor penting dalam perkembangan karir siswa, melalui pendidikan individu berharap dapat mewujudkan cita-cita dan mencapai kehidupan yang bermakna baik bagi diri sendiri, maupun orang-orang di sekitarnya. Berkenaan dengan karir, remaja dan perkembangan arah karir remaja. Hurlock (2005: 221) mengemukakan bahwa minat pada karir seringkali menjadi sumber pikiran pada masa remaja.

Karir salah satunya berkaitan dengan lapangan kerja. Siswa tentunya membutuhkan lapangan kerja yang akan dipergunakannya sebagai alat untuk bertahan hidup serta memperbaiki kualitas kehidupan setelah dirinya memasuki dunia karir. Olehnya itu, aspek perencanaan karir memegang peranan penting dalam pemilihan karir siswa. Perencanaan karir sebaiknya diperkenalkan pada siswa sejak berada pada bangku sekolah. Jika hal demikian terjadi maka siswa akan mampu memiliki orientasi dan pengambilan keputusan yang matang mengenai karir mereka di masa depan. Akan tetapi bila hal itu tidak terlaksana maka siswa sering memandang eksplorasi karir dan pengambilan keputusan disertai dengan kebimbangan, ketidakpastian dan stress (Santrock, 2003: 485). Pandangan ini menunjukkan bahwa perencanaan karir hendaklah dimiliki oleh setiap siswa untuk membantunya dalam melewati tahapan perkembangan karir selanjutnya.

Perencanaan karir penting dilakukan untuk mengidentifikasi tujuan sekaligus membantu menggambarkan peluang-peluang tentang pola karir di masa depan. Kidd (2006: 47) mengemukakan bahwa perencanaan karir dan keterampilan manajemen karir akan dibutuhkan di masa depan dan telah tergambar melalui perdebatan mengenai pekerjaan di masa depan. Untuk itu, aspek perencanaan karir perlu dimatangkan sejak siswa berada pada bangku sekolah untuk menghindari terjadinya pengambilan keputusan karir yang salah.

Berdasarkan studi dokumentasi guru Bimbingan dan Konseling (BK) Sekolah Menengah Pertama (SMP) Negeri 1 Konawe, terungkap bahwa siswa belum mampu mengembangkan kompetensi karirnya. Indikator yang nampak adalah siswa-siswa belum mampu untuk menjelaskan akan kemana nanti setelah lulus dari sekolah. Ada rasa bimbang untuk memilih studi lanjut apakah akan ke Sekolah Menengah Atas (SMA) ataukah Sekolah Menengah Kejuruan (SMK) atau ke sekolah lain yang sederajat. Temuan lain yang diperoleh adalah ada beberapa siswa yang telah tahu akan kemana nanti setelah lulus SMP, akan tetapi ini terjadi karena siswa yang bersangkutan ternyata hanya mengikuti perkataan teman-temannya dengan maksud agar setelah lulus nanti tidak terpisah dengan teman kelompoknya. Selain itu, ditemukan pula bukti bahwa siswa masih terpaku pada arahan orang tua mengenai arah kelanjutan sekolah siswa itu sendiri.

Fenomena tersebut menggambarkan bahwa siswa-siswa tersebut belum mampu merencanakan karirnya dengan baik. Hal ini bertentangan dengan salah satu karakteristik yang menonjol pada siswa SMP yaitu adanya kecenderungan minat dan pilihan karir yang relatif sudah lebih jelas (Desmita, 2011: 36).

Uraian mengenai ketidakmampuan siswa untuk merencanakan karirnya ke depan perlu ditelusuri penyebabnya. Penelusuran untuk mengidentifikasi penyebab ketidakmampuan siswa melakukan perencanaan karir dapat ditinjau dari faktor-faktor yang memengaruhi perencanaan karir itu sendiri. Adiputra (2015: 47) mengemukakan bahwa aspek karir dipengaruhi oleh faktor internal dan faktor eksternal. Faktor internal berkaitan dengan faktor di dalam diri individu sedangkan faktor eksternal berkaitan dengan faktor yang ada di luar diri individu. Faktor internal berhubungan dengan faktor fisik/ jasmaniah dan faktor psikologis. Adapun faktor eksternal berhubungan dengan faktor keluarga serta lingkungan.

Siswa dalam merencanakan karir dikehendaki mengutamakan faktor internal daripada faktor eksternalnya. Hal ini dikarenakan faktor internal merupakan faktor bawaan yang merupakan potensi diri yang dimiliki siswa. Faktor eksternal dapat menjadi faktor pendukung akan hal tersebut. Berkaitan dengan hal tersebut maka identifikasi mengenai faktor internal perencanaan karir siswa perlu dilakukan. Meskipun demikian, faktor internal yang terdiri atas faktor jasmani dan faktor psikologis perlu dikaji lebih mendalam. Faktor jasmani berkaitan erat dengan kondisi fisik individu yang bukan merupakan wilayah objek praktik spesifik BK. Olehnya itu, faktor psikologis siswa mengenai perencanaan karirnya akan ditelusuri secara lebih lanjut. 
Berkaikan dengan uraian sebelumnya, peneliti tertarik untuk meneliti faktor-faktor psikologis yang memengaruhi kemampuan perencanaan karir siswa SMP Negeri 1 Konawe Kabupaten Konawe. Pertimbangan untuk meneliti faktor-faktor psikologis yang memengaruhi perencanaan karir yaitu dengan mengenal faktorfaktor psikologis tersebut nantinya bisa membantu memahami perkembangan karir siswa terutama dalam perencanaan karir. Pemahaman mendalam mengenai faktor psikologis yang memengaruhi diharapkan dapat menjadi bekal untuk merumuskan upaya penanganan yang efektif. Oleh karena itu peneliti tertarik untuk melakukan penelitian dengan judul "Faktor-faktor Psikologis yang Memengaruhi Perencanaan Karir Siswa”. Tujuan dalam penelitian ini adalah untuk mengetahui Faktor-faktor psikologis apa saja yang memengaruhi perencanaan karir siswa.

Perencanaan karir adalah sebuah tahapan awal dalam fase pengembangan karir yang dijalani melalui pemahaman akan kemampuan diri individu yang disertai dengan kesanggupan untuk mengidentifikasi jalur karir mana yang akan ditempuh berdasarkan potensi diri individu. Melalui perencanaan karir maka akan timbul berbagai alternatif jalur karir yang akan dijalani. Alternatif-alternatif yang timbul kemudian perlu disikapi dan dipertimbangkan untuk mencegah timbulnya kesalahan dalam memilih jalur karir yang tepat sesuai kemampuan diri.

Kemampuan perencanaan karir siswa tidak muncul begitu saja dengan sendirinya. Perencanaan karir dipengaruhi oleh berbagai faktor. McMahon \& Patton (dalam Kayalar \& Ozmutaf, 2009: 241) mengemukakan bahwa faktor-faktor paling signifikan yang memengaruhi perencanaan karir individu adalah usia, gender, pendidikan, kehidupan sosial, ekonomi dan dinamika lingkungan. Selanjutnya, Tarigan \& Wimbarti (2011: 77) menjelaskan bahwa elemen penting dalam perencanaan karir adalah pendalaman diri (self discovery), evaluasi diri, nilai-nilai pribadi dan hasil pengalaman belajar pada lingkungan.

Cavus, Geri, \& Turgunbayeva (2015: 98) berdasarkan hasil penelitiannya menemukan bahwa faktor-faktor yang memengaruhi perencanaan karir adalah karakteristik pribadi (seperti minat dan bakat), kemampuan/ keterampilan, tingkat ekonomi serta tingkat atau level pendidikan/ pengetahuan. Waddel \& Bauer (2005: 4) menjelaskan bahwa faktor self discovery merupakan faktor fundamental dalam perencanaan karir. Self discovery dapat diperoleh melalui penilaian diri dalam bentuk konsep diri/ self concept. Ditambahkan pula oleh SidiropoulouDimakakou, Mylonas, \& Argyropoulou (2015: 41) dan Nag (2014: 507) bahwa faktor self efficacy juga turut memengaruhi perencanaan karir manusia.

\section{Metode Penelitian}

Penelitian ini dilakukan di SMP Negeri 1 Konawe pada bulan Juli sampai dengan Oktober 2018 atau kurang lebih selama tiga (3) bulan. Penelitian ini dilaksanakan dengan menggunakan pendekatan kuantitatif. Jenis pendekatan kuantitatif yang digunakan adalah deskriptif. Penelitian deskriptif merupakan penelitian yang dilakukan untuk mengetahui nilai variabel mandiri, baik satu variabel atau lebih tanpa membuat perbandingan atau menghubungkan dengan variabel yang lain (Sugiyono, 2012: 13). Alasan mengenai pertimbangan penggunaan penelitian deskriptif adalah bahwa penelitian ini ditujukan untuk mengetahui faktor-faktor psikologis yang memengaruhi perencanaan karir siswa serta faktor dominannya.

Populasi dalam penelitian ini adalah seluruh siswa yang aktif dan terdaftar di di SMP Negeri 1 Konawe pada tahun pelajaran 2018/ 2019 dengan jumlah 354 siswa. Sampel di dalam penelitian ini ditarik dengan menggunakan teknik simple random sampling. Populasi dalam penelitian ini berjumlah 354 dan sampel berjumlah 35 .

Penelitian ini terdiri dari satu variabel, yakni variabel faktor-faktor psikologis yang memengaruhi perencanaan karir. Agar tidak terjadi kekeliruan dalam menafsirkan variabel penelitian ini maka yang dimaksud dengan faktor-faktor psikologis yang memengaruhi perencanaan karir adalah hal-hal pada diri individu yang berkaitan dengan aspek di dalam dirinya yang memiliki kemampuan untuk memengaruhi tahap identifikasi jalur karir yang akan ditempuh berdasarkan potensi diri tersebut. Faktor-faktor psikologis yang dimaksudkan dalam penelitian ini adalah faktorfaktor psikologis berdasarkan hasil sintesis pendapat pendukung yang ada di kajian pustaka, yakni self-efficacy, skill, pengetahuan dan konsep diri.

Data di dalam penelitian ini dikumpulkan dengan menggunakan teknik skala. Skala dimaksudkan untuk mengukur sikap individu dalam dimensi dan menempatkan dirinya ke arah 
satu kontinuitas dari butir skala (Yusuf, 2014: 222). Adapun skala yang dimaksudkan disini adalah skala faktor-faktor psikologis yang memengaruhi perencanaan karir. Hasil akhir dari penilaian pada skala akan mengarahkan pada jawaban atas masalah dalam penelitian.

Data di dalam penelitian ini akan diolah dengan menggunakan statistika deskriptif. Alasan menggunakan statistika deskriptif adalah tujuan penelitian ini adalah untuk mengetahui faktorfaktor psikologis yang memengaruhi perencanaan karir. Data dianalisa dengan menggunakan rumus persentase sebagai berikut.

Keterangan:

$$
D P=\frac{n}{N} \times 100 \%
$$

$D P$ : Deskriptif persentase

$N$ : Skor yang diperoleh

$N$ : Skor maksimal aitem pernyataan (Riduwan, 2004: 94).

Berdasarkan rumus di atas dapat diketahui bahwa dalam menginterpretasikan faktor-faktor psikologis yang memengaruhi perencanaan karir siswa yang memiliki rentang skor 1-5 yang mewakili setiap kriteria yaitu Sangat Sesuai (SS), Sesuai (S), Kurang Sesuai (KS), Tidak Sesuai (TS) dan Sangat Tidak Sesuai (STS) dengan jumlah butir skala sebesar 30. Untuk menghitung masingmasing indikator, jumlah skor dari tiap responden ditransformasikan dalam bentuk persentase skor dengan cara sebagai berikut:

1. Menentukan skor jawaban dengan ketentuan untuk item positif dan negatif memunyai skor beda.

2. Menjumlahkan seluruh skor dalam setiap variabel yang diperoleh setiap responden.

3. Menghitung persentase skor maksimum ideal $\left(\mathrm{X}_{\max }\right)$

4. Menghitung persentase skor minimum ideal $\left(\mathrm{X}_{\min }\right)$

5. Menghitung rentangpersentase (R)

6. Menentukan interval kelas (i)

7. Membuat tabel kategorisasi

Berdasarkan langkah-langkah tersebut maka kategorisasi tingkat faktor-faktor yang memengaruhi perencanaan karir siswa dapat dilihat pada tabel 1 berikut:
Tabel 1

Kategorisasi Faktor-Faktor Psikologis yang Memengaruhi Perencanaan Karir

\begin{tabular}{|c|c|}
\hline Interval & Kategori \\
\hline $84 \%-100 \%$ & Sangat Kuat \\
$68 \%-83 \%$ & Kuat \\
$52 \%-67 \%$ & Cukup Kuat \\
$36 \%-51 \%$ & Lemah \\
$20 \%-35 \%$ & Sangat Lemah \\
\hline
\end{tabular}

Hasil persentase yang diperoleh pada tiaptiap indikator selanjutnya akan diinterpretasikan sifat pengaruhnya berdasarkan kategori yang dirumuskan. Indikator yang memiliki persentase terbesar merupakan faktor determinan yang memengaruhi perencanaan karir siswa.

\section{Hasil Penelitian dan Pembahasan \\ Hasil penelitian}

Berdasarkan penelitian yang telah dilaksanakan, di bawah ini akan dipaparkan hasil penelitian secara deskriptif kuantitatif. Hasil penelitian secara kuantitatif melalui analisis data tersebut digunakan untuk mengetahui faktor-faktor psikologis yang memengaruhi perencanaan karir siswa SMP Negeri 1 Konawe. Teknik analisis data yang digunakan adalah distribusi frekuensi. Pengambilan data menggunakan skala tertutup yang ditujukan kepada 35 siswa SMP Negeri 1 Konawe.

Faktor-faktor psikologis yang diteliti di dalam penelitian ini ada empat, yaitu self-efficacy, skill (keterampilan), pengetahuan dan konsep diri. Berikut paparan hasil penelitian untuk setiap faktor.

Tabel 2

Deskripsi Pengaruh Faktor Self-Efficacy

Terhadap Perencanaan Karir Pada Siswa SMP Negeri 1 Konawe

Statistics
Self-Efficacy
\begin{tabular}{|l|r|}
\hline \multicolumn{1}{|c|}{ Valid } \\
\multicolumn{1}{|c|}{ Missing } & 35 \\
Mean & 0 \\
Mode & 70.182 \\
Std. Deviation & 61.82 \\
Minimum & 12.667 \\
Maximum & 49.09 \\
\hline
\end{tabular}

Berdasarkan tabel 2 tersebut, diketahui bahwa nilai minimun sebesar 49,09. Nilai ini bila dikaitkan dengan norma kategorisasi berarti bahwa 
terdapat siswa yang perencanaan karirnya disebabkan oleh faktor self-efficacy meskipun itu sifat pengaruhnya lemah. Diketahui pula bahwa nilai maksimum sebesar 90,91. Nilai ini bila dikaitkan dengan norma kategorisasi berarti bahwa terdapat siswa yang perencanaan karirnya disebabkan oleh faktor self-efficacy dengan sifat pengaruh yang sangat kuat.

Secara umum, diketahui bahwa nilai persentase rata-rata (mean) dalam kelompok sebesar 70,1820. Nilai ini bila diterjemahkan ke dalam norma kategorisasi berarti bahwa faktor self-efficacy menyebabkan terjadinya perencanaan karir dengan sifat pengaruh yang kuat. Dengan demikian diketahui bahwa faktor self-efficacy mampu menjadi faktor yang memunculkan perencanan karir pada siswa SMP Negeri 1 Konawe dengan sifat pengaruh yang kuat.

Faktor psikologis kedua yang diteliti di dalam penelitian ini adalah faktor skill (keterampilan). Berikut disajikan deskripsi pengaruh faktor skill melalui tabel berikut:

Tabel 3

\section{Deskripsi Pengaruh Faktor Skill Terhadap Perencanaan Karir Siswa SMP Negeri 1 Konawe}

Statistics
Skill
\begin{tabular}{|l|r|}
\hline \multicolumn{1}{|c|}{ Valid } & Missing \\
Mean & 0 \\
Mode & 64.6857 \\
Std. Deviation & $50.00^{\mathrm{a}}$ \\
Minimum & 14.45433 \\
Maximum & 36 \\
\hline
\end{tabular}

Berdasarkan tabel 3 diketahui bahwa nilai minimun sebesar 36. Nilai ini bila dikaitkan dengan norma kategorisasi berarti bahwa terdapat siswa yang perencanaan karirnya disebabkan oleh faktor skill meskipun itu sifat pengaruhnya lemah. Diketahui pula bahwa nilai maksimum sebesar 90. Nilai ini bila dikaitkan dengan norma kategorisasi berarti bahwa terdapat siswa yang perencanaan karirnya disebabkan oleh faktor skill dengan sifat pengaruh yang sangat kuat. Secara umum diketahui bahwa nilai persentase rata-rata (mean) dalam kelompok sebesar 64,6857. Nilai ini bila diterjemahkan ke dalam norma kategorisasi berarti bahwa faktor skill berpengaruh cukup kuat terhadap perencanaan karir siswa. Dengan demikian, diketahui bahwa faktor skill mampu menyebabkan perencanaan karir siswa SMP
Negeri 1 Konawe dengan sifat pengaruh yang cukup kuat.

Faktor psikologis ketiga dalam penelitian ini adalah faktor pengetahuan. Berikut disajikan deskripsi pengaruh faktor pengetahuan melalui tabel 4.

Tabel 4

\section{Deskripsi Pengaruh Faktor Pengetahuan Terhadap Perencanaan Karir Siswa SMP Negeri 1 Konawe}

\section{Statistics}

Pengetahuan

\begin{tabular}{|l|r|}
\hline \multicolumn{1}{|c|}{$\mathrm{N} \quad \begin{array}{r}\text { Valid } \\
\text { Missing }\end{array}$} & 35 \\
Mean & 07.4286 \\
Mode & 65 \\
Std. Deviation & 17.25123 \\
Minimum & 40 \\
Maximum & 95 \\
\hline
\end{tabular}

Berdasarkan tabel 4 diketahui bahwa nilai minimun sebesar 40. Nilai ini bila dikaitkan dengan norma kategorisasi berarti bahwa terdapat siswa yang perencanaan karirnya disebabkan oleh faktor pengetahuan meskipun itu sifat pengaruhnya lemah. Diketahui pula bahwa nilai maksimum sebesar 95. Nilai ini bila dikaitkan dengan norma kategorisasi berarti bahwa terdapat siswa yang perencanaan karirnya disebabkan oleh faktor pengetahuan dengan sifat pengaruh yang sangat kuat. Secara umum diketahui bahwa nilai persentase rata-rata (mean) dalam kelompok sebesar 67,4286. Nilai ini bila diterjemahkan ke dalam norma kategorisasi berarti bahwa faktor pengetahuan berpengaruh cukup kuat terhadap perencanaan karir siswa. Dengan demikian diketahui bahwa faktor pengetahuan mampu menimbulkan perencanaan karir siswa SMP Negeri 1 Konawe dengan sifat pengaruh yang cukup kuat.

Faktor psikologis keempat atau yang terakhir dalam penelitian ini adalah faktor konsep diri. Berikut disajikan deskripsi pengaruh faktor konsep diri melalui tabel di bawah ini: 


\section{Tabel 5 \\ Deskripsi Pengaruh Faktor Konsep Diri Terhadap Perencanaan Karir Siswa SMP Negeri 1 Konawe}

Statistics
Konsep Diri
\begin{tabular}{|l|r|}
\hline \multicolumn{1}{|c|}{ Valid $\quad$ Missing } & 35 \\
& 0 \\
Mean & 66.0571 \\
Mode & $60.00^{\mathrm{a}}$ \\
Std. Deviation & 15.71426 \\
Minimum & 36 \\
Maximum & 96 \\
\hline
\end{tabular}

Berdasarkan tabel 5 diketahui bahwa nilai minimun sebesar 36. Nilai ini bila dikaitkan dengan norma kategorisasi berarti bahwa terdapat siswa yang perencanaan karirnya disebabkan oleh faktor konsep diri meskipun itu sifat pengaruhnya lemah. Diketahui pula bahwa nilai maksimum sebesar 96. Nilai ini bila dikaitkan dengan norma kategorisasi berarti bahwa terdapat siswa yang perencanaan karirnya disebabkan oleh faktor konsep diri dengan sifat pengaruh yang sangat kuat. Secara umum diketahui bahwa nilai persentase rata-rata (mean) dalam kelompok sebesar 66,0571. Nilai ini bila diterjemahkan ke dalam norma kategorisasi berarti bahwa faktor konsep diriberpengaruh cukup kuat terhadap perencanaan karir siswa. Dengan demikian diketahui bahwa faktor konsep diri mampu menimbulkan perencanaan karir siswa SMP Negeri 1 Konawe dengan sifat pengaruh yang cukup kuat.

Secara umum, hasil penelitian menunjukkan bahwa faktor self-efficacy berpengaruh kuat dalammemengaruhi perencanaan karir pada diri siswa. Adapun faktor skill, pengetahuan dan konsep diri berpengaruh cukup kuat terhadap perencanaan karir siswa. Nilai rata-rata pengaruh faktor self-efficacy terhadap perencanaan karir siswa sebesar $70,1820 \%$, nilai rata-rata pengaruh faktor skill terhadap perencanaan karir siswa sebesar $64,6857 \%$, nilai rata-rata pengaruh faktor pengetahuan terhadap perencanaan karir siswa sebesar $67,4286 \%$ dan nilai rata-rata pengaruh faktor konsep diri terhadap perencanaan karir siswa sebesar $66,0571 \%$.

Hasil penelitian ini menggambarkan bahwa faktor penyebab perencanaan karir siswa dari sifat pengaruhnya secara berturut-turut adalah faktor self-efficacy, faktor pengetahuan, faktor konsep diri dan faktor skill. Dengan demikian diketahui bahwa faktor self-efficacy merupakan faktor dominan penyebab perencanaan karir siswa SMP Negeri 1 Konawe.

\section{Pembahasan}

Karir merupakan kebutuhan bagi individu sebagai manifestasi atas tugas perkembangannya. Karir merupakan aspek dalam kehidupan yang perlu direncanakan. Perencanaan karir merupakan suatu tahapan proses pengambilan keputusan karir. Perencanaan karir merupakan kegiatan menyeleksi dan menghubungkan pengetahuan, fakta, imajinasi dan asumsi untuk masa yang akan datang sehubungan dengan aspek karir. Tujuannya adalah memvisualisasi dan memformulasi hasil yang diinginkan, urutan kegiatan yang diperlukan dan perilaku dalam batas-batas yang dapat diterima yang akan digunakan dalam pengambilan keputusan karir. Perencanaan karir di sini menekankan pada usaha penyeleksi yakni individu dan menghubungkan suatu dengan kepentingan masa depan serta usaha untuk mencapainya. Apa wujudnya yang akan datang itu bagaimana usaha untuk mencapainya merupakan kegiatan penyusun rencana perencanaan karir.

Berdasarkan kajian literatur yang ada pada kajian pustaka, diketahui bahwa perencanaan karir dipengaruhi oleh faktor-faktor psikologis. Dalam penelitian ini faktor-faktor psikologis yang dimaksud antara lain faktor self-efficacy, faktor skill, faktor pengetahuan dan faktor konsep diri. Hasil penelitian menunjukkan bahwa faktor selfefficacy berpengaruh kuat terhadap perencanaan karir siswa. sedangkan faktor skill, pengetahuan dan konsep diri berpengaruh cukup kuat terhadap perencanaan karir siswa SMP Negeri 1 Konawe.

Melalui norma kategorisasi yang dibuat diketahui bahwa faktor self-efficacy sifat pengaruhnya kuat terhadap perencanaan karir siswa. Faktor skill, pengetahuan dan konsep diri memiliki pengaruh yang cukup kuat terhadap perencanaan karir siswa. Hasil ini menggambarkan bahwa self-efficacy merupakan faktor psikologis yang secara dominan memengaruhi perencanaan karir siswa SMP Negeri 1 Konawe.

Utami \& Hudaniah (2013: 43) menjelaskan bahwa self-efficacy adalah persepsi diri sendiri mengenai seberapa bagus diri dapat berfungsi dalam situasi tertentu. Self-efficacy berhubungan dengan keyakinan bahwa diri memiliki kemampuan melakukan tindakan yang diharapkan. Self-efficacy sebagai suatu keyakinan seseorang akan kemampuannya untuk menyusun dan mengarahkan tingkah lakunya untuk mencapai 
hasil yang dikehendaki. Self-efficacy akan mengantarkan individu pada keyakinan bahwa dirinya bisa untuk menyusun, mengarahkan dan melakukan sesuatu. Hal ini merupakan dorongan dalam diri agar individu lebih merasa bahwa dirinya bisa untuk melakukan sesuatu untuk masa depannya. Berdasarkan penelitian Utami \& Hudaniah (2013), ditemukan bahwa self-efficacy memiliki korelasi yang kuat dengan kesiapan kerja siswa. Adapun salah satu bentuk kesiapan kerja siswa ditunjukkan melalui perencanaan karir yang jelas.

Self-efficacy atau efikasi diri memiliki kontribusi yang besar dalam beberapa aspek. Berdasarkan penelitian Paulsen \& Betz (dalam Santosa \& Himam, 2014: 3) diketahui bahwa siswa yang mengalami kebimbangan karir atau rendahnya efikasi diri dalam membuat keputusan karir juga menunjukkan adanya rasa tidak percaya diri dalam kemampuan dasar secara akademik. Hal ini mengisyaratkan bahwa individu yang tidak memiliki self-efficacy akan cenderung memandang dirinya kurang mampu dalam hal lain, tidak terkecuali pada perencanaan karir.

Pada aspek perencanaan karir faktor selfefficacy akan membentuk keyakinan pada diri siswa bahwa siswa akan dapat dengan sukses untuk menyelesaikan pilihan-pilihan yang muncul dalam kehidupan karirnya. Siswa yang memiliki self-efficacy yang tinggi akan menganggap pilihanpilihan karir yang banyak itu sebagai tantangan yang harus dilalui dibandingkan sebagai ancaman yang harus dihindari. Siswa yang memiliki selfefficacy yang tinggi juga relatif lebih mampu menetapkan tujuan yang menantang bagi mereka sendiri tentang masa depan karirnya serta menjaga komitmen yang kuat untuk mencapainya. Ketika mengalami kemunduran atau kegagalan maka mereka dapat memperbaiki kepercayaan diri secara cepat dan kemudian melipat gandakan usahanya. Apabila dikaitkan dengan penentuan keputusan karir maka dapat disimpulkan bahwa seseorang dengan self-efficacy yang tinggi dapat lebih yakin dalam menentukan karirnya yang diinginkan meskipun banyak terjadi perubahan di lingkungan sekitarnya.

Faktor kedua yang memiliki pengaruh terhadap perencanaan karir adalah skill atau keterampilan. Keterampilan merupakan kecakapan dalam menyelesaikan tugas (Pusat Bahasa, 2008: 1505). Antoniu (2010: 16) menjelaskan bahwa keterampilan individu merupakan hal yang harus dievaluasi dalam merencanakan karir. Siswa yang memiliki keterampilan akan lebih mampu menetapkan rencana karirnya dibandingkan dengan siswa yang kurang memiliki keterampilan. Siswa yang menyadari keterampilannya akan terus mengasah keterampilannya sehingga yang bersangkutan lebih menjadi terampil lagi. Berbekal keterampilannya itu maka individu akan fokus mengembangkan karirnya berdasarkan keterampilan yang dimilikinya. Hal ini tentunya akan mendorong siswa untuk lebih menspesifikkan jalur karir yang akan dipilih dan pada akhirnya siswa akan mampu untuk menetapkan rencana karirnya ke depan.

$\begin{array}{ccrc}\text { Faktor } & \text { ketiga } & \text { yang } & \text { memengaruhi } \\ \text { perencanaan } & \text { karir } & \text { adalah } & \text { pengetahuan. }\end{array}$ Pengetahuan dimaknai sebagai kesanggupan individu untuk mengolah informasi yang diperoleh melalui panca inderanya. Pengetahuan berkaitan dengan banyaknya informasi yang dimiliki individu. Informasi tersebut berkaitan dengan pemahaman potensi diri serta hal-hal yang berhubungan dengan dunia karir. Antoniu (2010: 14) menjelaskan bahwa individu harus memiliki pengetahuan tentang kemampuan dan aspirasinya. Hal ini akan mendukung pengembangan karirnya ke depan. Kaitannya dengan perencanaan karir adalah ketika siswa memiliki pengetahuan tentang potensi diri dan dunia kerja maka individu relatif lebih mampu untuk mencoba menyusun rencana pengembangan karirnya. Hal ini akan menjadikan siswa lebih mampu untuk menghadapi segala kemungkinan yang terjadi di masa depan.

Faktor terakhir yaitu konsep diri. Hurlock (2005: 237) menjelaskan bahwa konsep diri ialah konsep seseorang dari siapa dan apa dia itu. Konsep ini merupakan bayangan cermin, ditentukan sebagian besar oleh peran dan hubungan orang lain, apa yang kiranya reaksi orang terhadapnya. Dalam kehidupan sehari-hari seringkali individu menilai dirinya sendiri mengenai layak atau tidak layakkah dirinya untuk melakukan sesuatu. Penilaian ini pula seringkali dibawa individu dalam meramalkan masa depannya, misalnya dalam menghadapi dunia kerja. Semakin positif penilaian individu terhadap dirinya maka besar kemungkinan individu akan lebih mampu untuk memantapkan rencana karirnya. Hal ini berbanding terbalik dengan individu yang menilai negatif dirinya sehingga menjadikan dirinya pesimis dalam hal merancang masa depannya.

Implikasi dari hasil penelitian ini adalah bahwa guru BK sebagai pelaksana kegiatan $\mathrm{BK}$ di 
sekolah hendaknya memerhatikan faktor selfefficacy, pengetahuan, keterampilan dan konsep diri bagi pengembangan karir siswa. Besarnya pengaruh keempat faktor psikologis tersebut terhadap perencanaan karir siswa hendaknya diperhatikan dalam pelayanan konseling karir pada siswa di sekolah. Tidak hanya itu, diperlukan pula upaya-upaya yang realistis oleh guru BK dalam membantu siswa untuk mengembangkan keempat faktor tersebut pada diri siswa. Upaya-upaya tersebut dapat merupakan upaya pengoptimalan layanan-layanan BK yang telah dilakukan sekolah atau mungkin upaya pelaksanaan inovasi-inovasi baru dalam pelayanan BK yang telah dilakukan. Upaya-upaya tersebut tentunya merupakan niatan baik untuk mengembangkan kompetensi karir siswa di sekolah.

\section{Kesimpulan dan Saran \\ Kesimpulan}

Berdasarkan hasil temuan dalam penelitian

ini, dapat disimpulkan bahwa faktor-faktor psikologis yang memengaruhi perencanaan karir siswa SMP Negeri 1 Konawe yaitu self-efficacy, skill, pengetahuan dan konsep diri. Faktor selfefficacy memiliki pengaruh yang besar terhadap perencanaan karir siswa SMP Negeri 1 Konawe sedangkan faktor skill, pengetahuan dan konsep diri memiliki pengaruh yang sedang dan faktor psikologis yang secara dominan memengaruhi perencanaan karir siswa SMP Negeri 1 Konawe adalah faktor self-efficacy.

\section{Saran}

Berdasarkan kesimpulan terdapat beberapa saran yang diajukan kepada berbagai pihak antara lain:

1. Bagi sekolah. Pihak sekolah hendaknya membuat program sekolah yang mampu mengembangkan self-efficacy pada siswa sehingga siswa akan menjadi pribadi yang memiliki optimisme yang tinggi dalam menghadapi tuntutan masa depan.

2. Bagi guru BK. Guru BK senantiasa mengembangkan kompetensi profesionalnya dalam konteks kinerjanya sehari-hari. Guru BK juga senantiasa mempertimbangkan faktor self-efficacy dalam pelayanan konseling karir di sekolah tanpa mengesampingkan faktorfaktor psikologis lainnya.

3. Bagi siswa. Dalam pengembangan karir yang semakin kompleks siswa dituntut agar lebih mampu mandiri dalam mengembangkan karirnya. Bila ada masalah menyangkut hal karir maka jangan ragu untuk menyampaikannya ke pihak sekolah, utamanya guru BK.

4. Bagi penelitian lanjutan. Bagi peneliti yang ingin melanjutkan penelitian ini sekiranya dapat melakukan penelitian untuk mengetahui hal-hal apa saja yang mampu meningkatkan faktor self-efficacy pada siswa.

\section{Daftar Pustaka}

Adiputra, S. (2015). Penggunaan Teknik Modeling Terhadap Perencanaan Karir Siswa. Jurnal Fokus Konseling, 1 (1), 45 - 56.

Antoniu, E. (2010). Career Planning Process and Its Role In Human Resource Development. Journal Annals of the University of Petroşani, Economics, 10 (2), 13 - 22.

Arikunto, Suharsimi. (2008). Prosedur Penelitian Suatu Pendekatan Praktik. Jakarta: PT. Rineka Cipta.

Desmita. (2011). Psikologi Perkembangan Peserta Didik. Bandung: PT. Remaja Rosdakarya.

Hurlock, Elizabeth B. (2005). Psikologi Perkembangan. Jakarta: Erlangga.

Kidd, J.M. (2006). Understanding Career Counselling: Theory, Research and Practice. London: Sage Publication.

Riduwan. (2004). Metode dan Teknik Menyusun Tesis. Bandung: Alfabeta.

Santrock, John W. (2003). Adolescence: Perkembangan Remaja (Edisi Keenam). Jakarta: Erlangga.

Sugiyono. (2012). Metode Penelitian Kuantitatif, Kualitatif dan $R \& D$. Bandung: Alfabeta.

Utami, Y.G.D. \& Hudaniah. (2013). Self Efficacy dengan Kesiapan Kerja Siswa Sekolah Menengah Kejuruan. Jurnal Ilmiah Psikologi Terapan (JIPT), 1 (1), 40 - 52.

Yusuf, A.M. (2014). Metode Penelitian: Kuantitatif, Kualitatif dan Penelitian Gabungan. Jakarta: Kencana. 
E-ISSN : 2716-1765

Yusuf, Samsy. \& Nurihsan, Ahmad Juntika. (2006). Landasan Bimbingan dan Konseling. Bandung: PT. Remaja Rosdakarya. 
